\title{
UJI EFEK HIPOLIPIDEMIK EKSTRAK ETANOL KAYU SECANG (Caesalpinia sappan L.) TERHADAP TIKUS WISTAR (Rattus norvegicus) JANTAN
}

\author{
Safriani Rahman, Rachmat Kosman, Ika Indra Wijaya \\ Fakultas Farmasi Universitas Muslim Indonesia \\ Email : Safriani_Rahman@yahoo.com
}

\begin{abstract}
Sappan wood contains brazilin compounds that acts as antioxidants to inhibit the cholesterol synthesis, so it is efficacious hypolipidemic. It has been conducted the research on hypolipidemic effect assay of ethanol extract of sappan wood against male wistar rats. This research aims to determine the hypolipidemic effect from the ethanol extract of sappan wood based on a decrease in cholesterol content of rats. This research used 15 male rats were divided into 5 groups. Group I (control) was given suspension Na. CMC 1\%, group II (comparator) was given simvastatin, the groups III, IV, and $V$ were given ethanol extract of sappan wood at a dose $75 \mathrm{mg} / \mathrm{kgbw}, 150 \mathrm{mg} / \mathrm{kgbw}$, and $300 \mathrm{mg} / \mathrm{kgbw}$. All provisions were done orally once a day for 14 days. Cholesterol content measurements were done at the beginning of cholesterol before induction, after induction and after treatment. Before treatment rats were induced with propylthiouracil $0.01 \%$ and high cholesterol diet. The results showed that the ethanol extract of the sappan wood has a hypolipidemic effect and a dose $300 \mathrm{mg} / \mathrm{kgbw}$ was not significantly different $(p>0.05)$ with simvastatin.
\end{abstract}

Key words: Hypolipidemic, sappan wood, Caesalpinia sappan L., antioxidants.

\section{PENDAHULUAN}

Hiperlipidemia adalah kondisi kadar kolesterol dan atau trigliserida meningkat melebihi batas normal yaitu kadar kolesterol total lebih dari $200 \mathrm{mg} / \mathrm{dL}$ dan kadar trigliserida lebih dari $150 \mathrm{mg} / \mathrm{dL}$. Hiperlipidemia merupakan penyebab utama aterosklerosis dan penyakit terkait aterosklerosis lainnya, seperti penyakit jantung koroner (coronary heart disease, $\quad \mathrm{CHD}$ ), penyakit serebrovaskular iskemia, dan penyakit pembuluh perifer (Suyatna, 2011; Goodman and Gilman, 2011; Ayuningtyas and Wahyuni, 2012).

Di Indonesia prevalensi hiperkolesterolemia pada usia 25-34 tahun adalah 9,3\% sedangkan pada usia 55-64 tahun sebesar 15,5\%. Faktor risiko terjadinya antara lain adalah faktor genetik, pola makan, dan kurangnya aktivitas olahraga. Laporan WHO tahun 2011, 17,5 juta 
Uji efek hipolipidemik ekstrak etanol kayu secang (Caesalpinia sappan L.) terhadap tikus wistar (Rattus norvegicus) jantan

orang meninggal dunia akibat penyakit kardiovaskuler atau 30\% kematian didunia dan diperkirakan jumlahnya akan meningkat mencapai 19 juta pada tahun 2020 (Arief et al.,2012; Malik et al., 2013; Dewi, 2013).

Penggunaan obat sintetik pada pengobatan hiperlipidemia dapat menimbulkan beberapa efek samping seperti kemerahan kulit yang hebat (disertai rasa hangat yang tidak nyaman) dan pruritus. Selain itu dapat juga menyebabkan gangguan pada saluran cerna yang ringan dan menyebabkan gangguan pada saluran cerna, seperti konstipasi, mual dan kembung (Harvey and Champe, 2013).

Oleh karena itu, penggunaan obat tradisional dapat dijadikan sebagai salah satu alternatif upaya preventif. Obat tradisional diharapkan dapat berperan dalam usaha pencegahan dan pengobatan penyakit serta dapat meningkatkan taraf kesehatan masyarakat. Tanaman yang secara empiris dipercaya oleh masyarakat mempunyai khasiat sebagai obat tradisional adalah kayu secang (Caesalpinia sappan L.). Masyarakat menggunakan kayu secang (Caesalpinia sappan L.). sebagai obat diabetes mellitus (Kumala et al., 2009; Fitriarini and Murwani, 2014).
Kayu secang (Caesalpinia sappan L.) memiliki kandungan kimia yaitu tannin, saponin, fotosterol, asam tanat, gelatin, resin, resorsin, brazilin, brazilein, minyak atsiri dan pigmen. Basilin/brazilin adalah golongan senyawa yang memberi warna merah pada kayu secang dengan struktur $\mathrm{C}_{6} \mathrm{H}_{14} \mathrm{O}_{5}$ dan termasuk dalam golongan flavonoid sebagai isoflavonoid yang merupakan senyawa antioksidan yang mempunyai katekol dalam struktur kimianya. Flavonoid mampu memperbaiki fungsi endotel pembuluh darah, dapat mengurangi kepekaan LDL terhadap pengaruh radikal bebas dan dapat bersifat hipolipidemik, antiinflamasi, serta sebagai antioksidan (Hasriani, 2012; Sumardika and Jawi, 2012; Lestari et al., 2013).

Berdasarkan hal tersebut di atas, maka akan dilakukan penelitian uji efek hipolipidemik ekstrak etanol kayu secang (CaesalpiniasappanL.) terhadap tikus wistar jantan (Rattus novergicus).

\section{METODE PENELITIAN}

\section{Alat dan Bahan}

Alat yang digunakan adalah alat-alat gelas (pyrex), batang pengaduk, cawan porselin, human analyzer, kandang tikus, mikropipet, penangas air, rotavapor, sendok 
Uji efek hipolipidemik ekstrak etanol kayu secang (Caesalpinia sappan L.) terhadap tikus wistar (Rattus norvegicus) jantan

tanduk besi, sentrifuge (sentrifuge PLC series), sonde, spoit $1 \mathrm{~mL}$, spoit $5 \mathrm{~mL}$, tabung eppendorf, timbangan analitik (O,hauss), timbangan kasar (triple beam), dan toples.

Bahan yang digunakan yaitu air suling, aluminium foil, betadine ${ }^{\circledR}$, EDTA, ekstrak etanol kayu secang (Caesalpinia sappan L.), etanol 96\%, kapas, makanan kolesterol, Natrium karboksi metil selulosa (Na-CMC), Propiltiourasil, reagen penguji kolesterol total, dan simvastatin.

\section{Prosedur Kerja}

\section{Pengambilan dan pengolahan sampel}

Sampel yang digunakan dalam penelitian adalah kayu secang (Caesalpinia sappan L.) yang diperoleh dari daerah Kabupaten Luwu. Sampel kayu secang (Caesalpinia sappan L.) yang diperoleh dikumpulkan dan dicuci bersih terlebih dahulu. Kemudian dilakukan perajangan dan dikeringkan dengan cara diangin-anginkan pada ruang terbuka tanpa terkena sinar matahari. Setelah kering sampel dihaluskan.

\section{Pembuatan bahan penelitian}

a. Pembuatan ekstrak etanol kayu secang (Caesalpinia sappan L.)

Sebanyak $500 \mathrm{~g}$ kayu secang (Caesalpinia sappan L.) dimasukkan ke dalam wadah maserasi. Kemudian wadah diisi dengan etanol $96 \%$ sebanyak 1000 $\mathrm{mL}$ dan didiamkan selama $5 \times 24$ jam dengan pengadukan beberapa kali, kemudian disaring dan ampasnya direndam kembali dengan cairan penyari yang baru, hasil penyarian yang diperoleh dipekatkan dengan menggunakan rotavapor sampai diperoleh ekstrak etanol pekat, kemudian diuapkan kembali lagi hingga didapatkan ekstrak kental.

b. Pembuatan Suspensi Natrium Karboksimetilselulosa (Na.CMC) $1 \%$

Sebanyak 1 gram Na.CMC dimasukkan sedikit demi sedikit ke dalam $50 \mathrm{~mL}$ air suling panas $\left(70^{\circ} \mathrm{C}\right)$ sambil diaduk dengan batang pengaduk elektrik sehingga terbentuk larutan koloidal hingga homogen, volume dicukupkan dengan air suling sampai $100 \mathrm{~mL}$.

c. Pembuatan suspensi propiltiourasil $0.01 \%$

Sebanyak $\quad 1,228 \quad g$ Propiltiourasi $^{\circledR}$ dilarutkan dengan air suling sedikit demi sedikit sambil digerus sampai homogen lalu dicukupkan volumenya sampai $1000 \mathrm{~mL}$. 
Uji efek hipolipidemik ekstrak etanol kayu secang (Caesalpinia sappan L.) terhadap tikus wistar (Rattus norvegicus) jantan

\section{d. Pembuatan}

\section{Simvastatin $1,029 \mathrm{mg} / \mathrm{kg}$}

\section{Sebanyak}

0,013

suspensi

Simvastatin ${ }^{\circledR}$

disuspensikan

dengan suspensi Na.CMC 1\%

sedikit demi sedikit sambil digerus

sampai homogen lalu dimasukkan kedalam vial dan volumenya dicukupkan sampai $6 \mathrm{~mL}$.

e. Pembuatan suspensi ekstrak kayu secang (Caesalpinia sappan L.)

Ekstrak kayu secang dibuat dalam dosis $75 \mathrm{mg} / \mathrm{kgBB} ; 150$ $\mathrm{mg} / \mathrm{kgBB}$, dan $300 \mathrm{mg} / \mathrm{kgBB}$. Cara untuk membuat dosis ekstrak kayu secang dosis $75 \mathrm{mg} / \mathrm{kgBB}$ adalah menimbang 0,045 gram ekstrak Tabel 1. Komposisi Pakan Standar etanol kayu secang kemudian digerus dalam lumpang dan ditambahkan sedikit demi sedikit suspensi Na.CMC 1\%, lalu dimasukkan dalam vial dan dicukupkan volumenya hingga 6 mL dengan suspensi Na. CMC 1\%. Sedangkan untuk dosis ekstrak $150 \mathrm{mg} / \mathrm{kgBB}$ dan $300 \mathrm{mg} / \mathrm{kgBB}$ dilakukan hal yang sama dengan menimbang masing-masing ekstrak sebanyak 0,09 gram dan 0,18 gram.

f. Pembuatan Pakan Diet Tinggi Kolesterol (Gani et al., 2013)

1. Pembuatan Pakan Standar Komposisi pakan standar dapat dilihat pada Tabel 1.

\begin{tabular}{clcc}
\hline No & Bahan-Bahan Campuran & Nama Bahan & Jumlah (\%) dalam 1000 g \\
\hline 1 & Protein & Putih telur & 10 \\
2 & Minyak & Bimoli & 8 \\
3 & Campuran multivitamin dan & Ultravita & 1 \\
& mineral & CMC & 1 \\
4 & Selulosa & Air & 5 \\
5 & Air & Pati jagung untuk membuat & Tepung jagung \\
6 & & \\
& $100 \%$ & \\
\hline
\end{tabular}

Semua bahan yang sudah disiapkan, dimasukkan dalam wadah dan dicampurkan dengan menggunakan blender hingga rata kemudian dipanaskan \pm 10 menit pada suhu $\pm 120^{\circ} \mathrm{C}$.
2. Pembuatan Pakan Diet Tinggi Kolesterol

Pakan dibuat dengan mencampurkan $100 \mathrm{~g}$ lemak kambing (10\%) dan $50 \mathrm{~g}$ kuning telur (5\%) dalam $1000 \mathrm{~g}$ pakan standar, lemak kambing 
Uji efek hipolipidemik ekstrak etanol kayu secang (Caesalpinia sappan L.) terhadap tikus wistar (Rattus norvegicus) jantan

dipanaskan dahulu hingga mencair, dan kuning telur diambil dari telur yang telah direbus.

\section{Pemilihan dan Penyiapan Hewan Uji}

Sebanyak 15 ekor tikus (Rattus norvegicus) dibagi dalam 5 kelompok perlakuan. Masing-masing kelompok terdiri dari 3 ekor tikus. Kelompok I (kontrol) yang diberikan suspensi $\mathrm{Na}$ CMC 1\%, kelompok II (pembanding) yang diberikan suspensi simvastatin $1,029 \mathrm{mg} / \mathrm{kg}$, kelompok III, IV, dan V adalah kelompok perlakuan yang diberikan ekstrak etanol kayu secang (Caesalpinia sappan L.) dengan dosis $75 \mathrm{mg} / \mathrm{kgBB}, 150 \mathrm{mg} / \mathrm{kgBB}$, dan 300 $\mathrm{mg} / \mathrm{kgBB}$. Hewan uji terlebih dahulu diadaptasi selama 1 minggu sebelum perlakuan.

\section{Perlakuan Hewan Uji}

Pada tahap pertama terlebih dahulu tikus putih dipuasakan selama \pm 8 jam setelah itu dilakukan pengambilan darah untuk pengukuran kadar kolesterol (kadar kolesterol awal). Tahap kedua diberikan makanan diet kolesterol tinggi dan larutan propiltiourasil selama 7 hari, setelah itu dilakukan pengukuran kadar kolesterol (kadar kolesterol induksi). Pada tahap ketiga yaitu tahap perlakuan, untuk kelompok I diberikan suspensi $\mathrm{Na}$ CMC 1\%, kelompok II diberikan suspensi simvastatin 1,029 $\mathrm{mg} / \mathrm{kg}$, kelompok III diberikan ekstrak etanol kayu secang (Caesalpinia sappan L.) $75 \mathrm{mg} / \mathrm{kgBB}$, kelompok IV diberikan ekstrak etanol kayu secang (Caesalpinia sappan L.) 150 mg/kgBB, dan kelompok $\mathrm{V}$ diberi ekstrak etanol kayu secang (Caesalpinia sappan L.) $300 \mathrm{mg} / \mathrm{kgBB}$. Pemberian dilakukan secara oral selama 14 hari dan pemberian makanan diet kolesterol tinggi dan minum dengan propiltiourasil. Pada hari ke 15 dilakukan pengukuran kadar kolesterol terapi (kadar kolesterol akhir).

\section{Pengambilan Sampel Darah Hewan} Uji (Nur, 2012)

Ekor tikus dijulurkan keluar dan vena lateralis pada ekor dipotong 0,2 $2 \mathrm{~cm}$ dari ujung ekor dengan gunting yang steril. Darah ditampung pada eppendorf untuk tujuan pengambilan serumnya. Kemudian diletakkan miring $45^{\circ}$ dan dibiarkan mengendap pada suhu kamar, selanjutnya dilakukan sentrifugasi untuk mendapatkan serum yang dimaksud.

\section{Pengukuran Kadar Kolesterol} Hewan Uji (Ariantari et al., 2010)

Darah dalam tabung dikocok pelan-pelan dan dimasukkan ke dalam sentrifugator dan disentrifugasi selama 10 menit dengan kecepatan 3000 rpm. Diambil serum yang terbentuk 
Uji efek hipolipidemik ekstrak etanol kayu secang (Caesalpinia sappan L.) terhadap tikus wistar (Rattus norvegicus) jantan

dilakukan pengukuran kadar kolesterol $20-25^{\circ} \mathrm{C}$ atau 10 menit pada suhu dengan cara sebanyak $10 \mu \mathrm{L}$ serum darah ditambahkan $1000 \mu \mathrm{L}$ pereaksi uji kolesterol dan larutan diaduk, $37^{\circ} \mathrm{C}$. Lalu dibaca dengan spektrofotometer pada panjang gelombang $500 \mathrm{~nm}$.

diinkubasi selama 20 menit pada suhu

\section{HASIL PENELITIAN}

Tabel 2. Hasil Pengukuran rata-rata kadar kolesterol sebelum Induksi (awal), setelah induksi dan setelah terapi (akhir) menggunakan ekstrak etanol kayu secang (Caesalpinia sappan L.) terhadap tikus wistar (Rattus norvegicus) jantan.

\begin{tabular}{lccc}
\hline \multicolumn{1}{c}{ Perlakuan } & \multicolumn{3}{c}{ Rata-rata Pengukuran Kadar Kolesterol (mg/dL) } \\
\cline { 2 - 4 } & Awal & Induksi & Akhir (Terapi) \\
\hline Kelompok I (NaCMC) & 28 & 119,33 & 90,33 \\
Kelompok II (Simvastatin) & 40,33 & 149,66 & 24,66 \\
Kelompok III (EEKS 75 mg/kgBB) & 37,66 & 166 & 49,33 \\
Kelompok IV (EEKS 150 mg/kgBB) & 35 & 167 & 37,33 \\
Kelompok V (EEKS 300 mg/kgBB) & 32,67 & 183,33 & 33,33 \\
\hline
\end{tabular}

Keterangan :

EEKS = Ekstrak Etanol Kayu Secang

Tabel 3. Persen penurunan kadar kolesterol induksi terapi dari uji efek hipolipidemik ekstrak etanol Kayu Secang (Caesalpinia sappan L.) terhadap tikus wistar (Rattus novergicus) jantan

\begin{tabular}{lc}
\hline \multicolumn{1}{c}{ Kelompok Perlakuan } & $\begin{array}{c}\text { Persen Penurunan Kadar Kolesterol (\%) } \\
\text { (induksi-terapi) }\end{array}$ \\
\hline Kelompok I Kontrol (Na.CMC) & 20,48 \\
Kelompok II Pembanding (Simvastatin ${ }^{\circledR}$ ) & 83,51 \\
Kelompok III EEKS 75mg/kgBB & 70,26 \\
Kelompok IV EEKS 150mg/kgBB & 77,38 \\
Kelompok V EEKS 300 mg/kgBB & 81,81 \\
\hline
\end{tabular}

\section{PEMBAHASAN}

Pada penelitian ini telah dilakukan uji efek hipolipidemik ekstrak etanol kayu secang (Caesalpinia sappan L.) terhadap tikus wistar (Rattus norvegicus) jantan. Penentuan efek penurunan kadar kolesterol dilakukan dengan cara mengukur kadar kolesterol tikus setelah pemberian ekstrak perlakuan selama 14 hari. Pengukuran kadar kolesterol menggunakan uji kalorimetrik enzimatik (metode CHOD-PAP). Metode tersebut mempunyai prinsip reaksi pembentukan Quinoneimine dari kolesterol. Kolesterol esterase 
Uji efek hipolipidemik ekstrak etanol kayu secang (Caesalpinia sappan L.) terhadap tikus wistar (Rattus norvegicus) jantan

menghidrolisa ester-ester dan hidrogen peroksida $\left(\mathrm{H}_{2} \mathrm{O}_{2}\right)$ dibentuk dari kolesterol dalam proses oksidasi enzimatik oleh kolesterol oksidasi. $\mathrm{H}_{2} \mathrm{O}_{2}$ bereaksi dengan 4aminoantipyrine dan phenol dengan katalisator peroksidase membentuk quinonimine yang berwarna. Senyawa ini mempunyai panjang gelombang ( $\lambda$ max) serapan pada $540 \mathrm{~nm}$ (Widyaningsih et al., 2010).

Hewan uji yang digunakan pada penelitian ini adalah tikus putih (Rattus norvegicus) jantan karena anatomis dan fisiologisnya memiliki karakteristik yang mirip manusia. Tikus jantan memiliki sistem hormonal yang lebih stabil dibandingkan dengan tikus betina. Tikus betina memiliki kadar kolesterol yang lebih tinggi saat hamil sehingga dapat mempengaruhi data hasil penelitian. Walaupun demikian, faktor variasi biologis tidak dapat dihilangkan sehingga faktor ini relative dapat mempengaruhi hasil (Warsono et al., 2004).

Oleh karena itu terdapat perbedaan konsentrasi kadar kolesterol awal pada tiap hewan coba, dalam hal ini dapat dilihat pada tabel 3. Data hasil pengukuran kadar kolesterol awal untuk tiap hewan tersebut yang berada pada kadar normal $10-54 \mathrm{mg} / \mathrm{dL}$. Pada tabel 3 terlihat bahwa akibat induksi propiltiourasil setelah 7 hari induksi terjadi peningkatan kadar kolesterol 23 kali lipat dari kadar awal. Kenaikan kadar kolesterol ini dapat dikatakan sebagai keadaan hiperlipidemia. Keadaan ini dapat terjadi karena propiltiourasil merupakan derivat pirimidin (analog dari metiltiourasil), berkhasiat sebagai tiroistatik. Propiltiourasil bekerja sebagai antitiroid yang menghambat sel-sel tiroid pada tikus sehingga produksi hormone tiroid terhambat pula dan mengakibatkan hipotiroidisme. Pengaruh langsung hipotiroidisme pada metabolisme lipoprotein adalah peningkatan kadar kolesterol, terutama LDL-kolesterol yang diakibatkan oleh penekanan metabolic pada reseptor LDL, sehingga kadar LDL-kolesterol akan meningkat (Febrina et al., 2009). Selain induksi secara endogen dilakukan pula induksi secara eksogen yaitu dengan pemberian makanan diet tinggi kolesterol.

Penelitian ini menggunakan ekstrak etanol kayu secang (Caesalpinia sappan L.). Ekstrak kayu secang mengandung lima senyawa yang terkait flavonoid, yang mempunyai aktivitas antioksidan primer dan sekunder yaitu brazilin, isomer brazilin, 1',4'-dihidrospiro 
Uji efek hipolipidemik ekstrak etanol kayu secang (Caesalpinia sappan L.) terhadap tikus wistar (Rattus norvegicus) jantan

[benzofuran-3(2H),3'-[3H

2]benzopiran] -1',6', 6',7'-tetrol, 3-[[4,5 dihidroksi-2-(hidroksimetil) fenil]metil]-

2-3-dihidro-3,6-benzofurandiol,

(7R,7S)-7,8-dihidro-3,7,10,11 tetrahidroksi- $6 \mathrm{H}$ - di benz[b,d] oksosin-7metanol (7R,7S-protosapanin B). Senyawa flavonoid merupakan senyawa yang memiliki aktivitas antioksidan khususnya dalam memerangkap radikal bebas. Flavonoid mengurangi sintesis kolesterol dengan cara menghambat aktivitas enzim acyl-CoA cholesterol acyl transferase (ACAT) pada sel HepG2 yang berperan dalam penurunan esterifikasi kolesterol pada usus dan hati, serta menghambat aktivitas enzim 3-hidroksi-3-metilglutaril-CoA yang menyebabkan penghambatan sintesis kolesterol (Arief et al., 2012).

Untuk melihat penurunan kadar kolesterol pada uji efek hipolipidemik ekstrak etanol kayu secang digunakan pembanding simvastatin, karena simvastatin merupakan salah satu obat yang dapat menurunkan kadar kolesterol dalam darah dengan baik. Simvastatin merupakan penghambat hidroksi- metil glutril koensim A (HMG $\mathrm{CoA}$ ) reduktase yang bekerja dengan menghambat sintesis kolesterol dihati dan hal ini akan menurunkan kadar
LDL kolesterol plasma yang mengkatalisis tahap awal pembatas laju pada biosintesis kolesterol (Suyatna, 2011).

Hasil penelitian uji efek hipolipidemik ekstrak etanol kayu secang (Caesalpinia sappan L.) dapat dilihat pada tabel 3 dan diagram batangnya dapat dilihat pada gambar 3. Untuk melihat adanya perbedaan nilai rata-rata kadar kolesterol sebelum induksi (awal) dengan setelah induksi, maka dilakukan uji analisis t-test berpasangan. Berdasarkan hasil analisis menunjukkan nilai rata-rata kadar kolesterol sebelum induksi dan setelah induksi menunjukkan bahwa data tersebut berbeda nyata $(p<0,05)$ dengan nilai signifikasi adalah 0,000 yang berarti penginduksian yang dilakukan berhasil yang ditandai terjadinya peningkatan kadar kolesterol awal.

Untuk melihat adanya penurunan kadar kolesterol pada tikus maka dihitung persen penurunan kadar kolesterol yang dapat dilihat pada tabel 4 . Pada tabel 4 terlihat semua kelompok mengalami penurunan kadar kolesterol tetapi tidak melebihi persen penurunan simvastatin. Pada kelompok kontrol $\mathrm{Na}-\mathrm{CMC}$ juga mengalami penurunan kadar kolesterol. Dimana hal ini terjadi 
Uji efek hipolipidemik ekstrak etanol kayu secang (Caesalpinia sappan L.) terhadap tikus wistar (Rattus norvegicus) jantan

kemungkinan dipengaruhi oleh berbagai faktor seperti besarnya nafsu makan, kondisi biologis, metabolisme tubuh serta perlakuan dari masingmasing tikus yang berbeda satu sama lain (Widyaningsih, 2011).

Untuk melihat kemampuan ekstrak etanol kayu secang dalam menurunkan kadar kolesterol maka dilakukan uji Kruskal Walis pada data terapi (akhir) untuk semua kelompok. Hasil analisis menunjukkan berbeda nyata dengan nilai signifikansi 0,016 . Hal ini berarti terjadi perbedaan kadar kolesterol akhir antara kelompok perlakuan. Untuk melihat perbedaan antara kelompok perlakuan maka dilakukan uji lanjutan dengan analisis Mann-Whitney. Hasil analisis menunjukkan untuk kadar kolesterol terapi kelompok Na-CMC terhadap semua kelompok menunjukkan hasil yang berbeda nyata. Hal ini berarti $\mathrm{Na}$ CMC tidak memberikan efek dalam menurunkan kadar kolesterol. Untuk kelompok simvastatin terhadap kelompok EEKS75 mg/kgBB dan EEKS 150 mg/kgBB menunjukkan hasil yang berbeda nyata. Ini berarti bahwa ekstrak memberikan efek yang berbeda dalam menurunkan kadar kolesterol. Untuk kelompok simvastatin terhadap kelompok EEKS 300 $\mathrm{mg} / \mathrm{kgBB}$ menunjukkan hasil yang tidak berbeda nyata. Hal ini berarti simvastatin dan ekstrak uji memiliki efek yang sama dalam menurunkan kadar kolesterol. Dari hasil penelitian yang telah dilakukan, ekstrak etanol kayu secang memiliki efek hipolipidemik pada konsentrasi 75 $\mathrm{mg} / \mathrm{kgBB}, 150 \mathrm{mg} / \mathrm{kgBB}$, dan 300 $\mathrm{mg} / \mathrm{kgBB}$. Berdasarkan perhitungan persen penurunan ekstrak etanol kayu secang, didapatkan hasil paling baik yaitu kelompok uji dengan dosis 300 $\mathrm{mg} / \mathrm{kgBB}$ yang nilai signifikansinya tidak berbeda nyata dengan simvastatin.

\section{KESIMPULAN}

Berdasarkan penelitian yang dilakukan dapat disimpulkan bahwa ekstrak etanol kayu secang (Caesalpinia sappan L.) dapat memberikan efek sebagai hipolipidemik dan yang paling efektif adalah dosis $300 \mathrm{mg} / \mathrm{kgBB}$ yang memiliki efek yang tidak berbeda nyata dengan pembanding.

\section{DAFTAR PUSTAKA}

Ariantari, N. P., Yowani, S. C., Swastini, D. A., 2010. Uji aktivitas penurunan kolesterol produk madu herbal yang beredar di pasaran pada tikus putih diet lemak tinggi. Jurnal Kimia. 4(1):15-19.

Arief, M.I., Novriansyah, R., Budianto, I.T., Harmaji, M.B., 2012. Potensi bunga karamunting ( 
Uji efek hipolipidemik ekstrak etanol kayu secang (Caesalpinia sappan L.) terhadap tikus wistar (Rattus norvegicus) jantan

Melastoma malabathricum L.) terhadap kadar kolesterol total dan trigliserida pada tikus putih jantan hiperlipidemia yang diinduksi propiltiourasil. Prestasi 1(2):118-126.

Ayuningtyas, E.D., Wahyuni, A.S., 2012. Profil kadar trigliserid darah tikus hiperkolesterolemi oleh ekstrak etanol jamur lingzhi (Ganoderma lucidum). Medika Planta. 2(1):26-35.

Dewi, N., 2013. Pengaruh pemberian ekstrak kacang hijau (Phaseolus radiatus) terhadap kadar kolesterol LDL serum tikus hiperkolesterolemia. Fakultas Kedokteran Universitas Diponegoro, Semarang.

Febrina, E., Halimah, E., Sumiwi, S.A., 2009. Aktivitas antihiperlipidemia ekstrak etanol herba seledri (Apium graveolens L.) dari daerah bandung barat. Fakultas Farmasi Universitas Padjadjaran, Bandung.

Fitriarini, S., Murwani, H., 2013. Perbedaan pengaruh antara ekstrak dan rebusan daun salam (Eugenia polyantha) dalam pencegahan penurunan kadar kolesterol HDL pada tikus sprague dawley. Jurusan IImu Gizi Fakultas Kedokteran Universitas Diponegoro, Semarang.

Gani, N., Momuat, L.I., Pitoi, M.M., 2013. Profil Lipida Plasma Tikus Wistar Yang Hiperkolesterolemia Pada Pemberian Gedi Merah (Abelmoschus manihot L.). Jurusan Kimia FMIPA Unsrat, MIPA Unsrat Online 2 (1):44-49.
Goodman dan Gilman, 2011. Manual Farmakologi dan Terapi, Penerbit Buku Kedokteran EGC, Jakarta.

Harvey, R.A. Champe, P.C., 2013. Farmakologi

Ulasan

BergambarEdisi 4. Penerbit Buku Kedokteran EGC, Jakarta.

Hasriani. 2012. Optimasi proses pengeringan simplisia kayu secang (Sappan lignum) dan aplikasinya pada produk makanan. Sekolah Pascasarjana Institut Pertanian Bogor, Bogor.

Kumala, S., Yuliani., Tulus, D., 2009. Pengaruh pemberian rebusan kayu secang (Caesalpinia sappan L.) terhadap mencit yang diinfeksi bakteri escherichia coli. Fakultas Farmasi Universitas Pancasila 4(4):188-198.

Lestari, N.P., Tjandrakirana., Kuswanti N., 2013. Pengaruh pemberian campuran rebusan secang (Caesalpinia sappan L.) dan daun lidah buaya (Aloe vera) terhadap kadar glukosa darah mencit (Mus musculus). Lentera Bio. 2(1):113-119.

Malik, M.A., Mewo, Y.M., Kaligis, S., 2013. Gambaran kadar kolesterol total darah pada mahasiswa angakatan 2011 fakultas kedokteran universitas sam ratulangi dengan indeks massa tubuh $18,5-22,9 \mathrm{~kg} / \mathrm{m}^{2}$, Fakultas Kedokteran Universitas Sam Ratulangi.

Nur, P., 2012. Instruksi kerja pengambilan darah, perlakuan, dan injeksi pada hewan coba, 
Uji efek hipolipidemik ekstrak etanol kayu secang (Caesalpinia sappan L.) terhadap tikus wistar (Rattus norvegicus) jantan

Laboratorium

Biosains

Universitas Brawijaya, Malang.

Sumardika, I.W., Jawi., I.M., 2012.

Ekstrak air daun ubijalar ungu memperbaiki profil lipid dan meningkatkan kadar SOD darah tikus yang diberi makanan tinggi kolesterol. MEDICINA 43(2):6770.

Suyatna, F.D., 2011. 'Hipolipidemik' in Sulistia G. Gunawan (ed), Farmakologi dan Terapi Edisi V, UI Press, Jakarta, Indonesia, 373-388.

Widyaningsih, W., Prabowo, A., dan Sumiasih, 2010, Pengaruh ekstrak etanol daging bekicot (Achantina fulica) terhadap kadar kolesterol total, HDL, dan LDL serum darah tikus jantan galur wistar. Jurnal Sains dan Teknologi Farmasi UAD 15(1): 1-10.

Widyaningsih, W, 2011, Efek ekstrak etanol rimpang temugiring (Curcuma heyneana Val.) terhadap kadar trigliserida, Jurnal Ilmiah Kefarmasian UAD 1(1):55-65.

Warsono, I.U., Fattah, W.M., Parakkasi, A., 2004. Pengaruh tepung cangkang rajungan (Portunus pelagicus) dalam ransum terhadap kadar kolesterol serum dan pertambahan bobot badan tikus putih (Rattus norvegicus). Media Peternakan. Fakultas Peternakan Universitas Padjadjaran 27(2):55-62. 